\title{
EVALUATION OF THE EFFECT OF COMPOST FROM BY-PRODUCTS OF JATROPHA CURCAS L. (EUPHORBIACEAE) ON SOIL FERTILITY AND PRODUCTIVITY OF SORGHUM (SORGHUM BICOLOUR (L.) MOENCH) IN BURKINA FASO
}

\author{
${ }^{1 *}$ Abdoul-Nassiré DERRA, ${ }^{2}$ Barthelemy YÉLÉMOU, ${ }^{1}$ Hemayoro SAMA, ${ }^{1}$ Adama HILOU \\ ${ }^{1}$ Laboratory of Biochemistry and Applied Chemistry (LABIOCA), \\ University Joseph KI-ZERBO 01 BP 7021 Ouagadougou, Burkina Faso. \\ ${ }^{2}$ Institute of Environment and Agricultural Research (INERA), \\ Department of Natural Resources Management and Production System, \\ INERA-Saria BP10 Koudougou, Burkina Faso. \\ *Corresponding Author
}

DOI: https://doi.org/10.51193/IJAER.2021.7408

\begin{abstract}
Modern agriculture faces to new challenges and problems. Application of organic waste compost represents new possibilities to improve soil organic matter and thus reduce the risk of soil degradation and improve significantly crop yield. This study was conducted to determine the effect of various compost-based Jatropha by-products on soil properties and sorghum (Sorghm bicolour L.) Moench) growth and production parameters. The treatments of the study corresponded to 13 formulations of Jatropha curcas based composts and a control treatment, which did not receive any application. The study showed that Jatropha by-products amendment could effectively raise soil fertility by increasing $\mathrm{pH}$ and nutrient contents and improved sorghum growth and production parameters. The results also showed positive and significant correlations between panicles yield and seeds yield as well as straws yield. Positive and significant correlations were recorded between seeds yield and straws yield and weight of 100 seeds. These correlations between the different parameters are important of simultaneous improving of growth and crops yield of sorghum. The ACP performed based on measurement parameters permitted to identify the appropriate formulation for any interest parameter. The CAH distinguished four classes of composts among which Jatropha biomass-based composts with groups 3 (BM_S and BM+BV) and $4(\mathrm{BM}+\mathrm{CP})$ are particularly interesting as these treatments are strongly associated with seeds, straw and panicle yields, sorghum spike height
\end{abstract}


growth and soil fertility improvement. These results supported the best effects of the application of various compost-based by-products of Jatropha curcas in sorghum production.

Keywords: Jatropha curcas, composts, sorghum, growth, crop yield

\section{INTRODUCTION}

In developing countries, particularly in sub-Saharan Africa, access to energy is a major constraint for the population. In fact, these countries are characterised by a dependence on fossil fuels, mainly imports, which account for nearly $39 \%$ of total energy consumption in sub-Saharan Africa (AfDB, 2006). These energy sources provide more than half of household and industrial electrification. Therefore, energy may become a constraint to the economic development of the region, on the one hand due to limited energy supply, on the other hand due to the high demand in the process of urbanisation. Hence the need to diversify energy sources (Dia et al., 2010). The issue of energy transition should be rethought by giving priority, not to access to modern lighting, but to productive energy services with a view to strengthening the creation of jobs, income and added value (Hanff et al., 2011). In Burkina Faso, many policy options are being implemented to reduce energy dependence and vulnerability, including the introduction of biofuels into agricultural systems. Oils and biodiesel derived from Jatrophacurcas are considered to be the best alternative to fossil fuels to reduce $\mathrm{CO}_{2}$ emissions and provide accessible energy to the most vulnerable populations (Janin and Ouédraogo, 2009). Although Jatropha does not require high soil fertility, its development requires good management to avoid soil competition between food and energy production (Firdaus and Husni, 2012). Previous studies have reported a good association of this species with food crops without harmful competition (Derra et al., 2013 ; Bazongo et al., 2015). However, this plant has always been known to be phytotoxic to humans and animals (Das and Chandran, 2011); this raised the question of the possible phytotoxicity of its biomass (residual or composted) in relation to adjacent cereal plants.

The reduction of tropical soil fertility and crop productivity is a major concern and indeed a great hindrance to achieving food sufficiency in the tropics (Olowoake et al., 2018). Farmers use mineral fertilizers to improve soil fertility (Powlson et al., 2011). However, the massive use of these fertilizers and some poor farming practices have greatly reduced the organic matter content of soils, directly influencing the physical, chemical and biological properties, and the risk of soil degradation. So, the main consequence of the aforementioned agronomic practices could be the mineralization and desertification of soils (Calderón et al., 2013). Organic fertilisers would be a good method of soil management and are used among others to reduce the adverse effects of synthetic fertilisers on human health and the environment (Diallo, 2011). In addition to being a source of nutrients for crops through its mineral component, organic manure improves the 
biological and physical properties of the soil through its organic component (Ganry et al., 2001; Khan et al., 2019). Among these organic fertilizers, compost is frequently advocated as a simple and inexpensive solution for a wide variety of agronomic, environmental and socio-economic problems (Ishola and Ishola, 2019). In agricultural soils, compost addition increases porosity, structural stability, boost the growth and activity of useful organisms in the soil, ease micronutrient deficiencies, and sustain higher yield due to better soil health (Tiwari, 2002; Singh et al., 2006).

The production of organic fertilisers is limited by the decrease in biomass production which restricts the possibility of compost production; hence the need to explore new sources of fertilisers based on agricultural by-products (Traore et al., 2015). Agricultural by-products that cannot be used for other purposes could be a solution to improve soil fertility at low cost in Sudano-Sahelian Africa (Olowoake, 2019). In this context, Jatropha is of particular interest because more than $85 \%$ of its seed biomass is not used to produce biofuel. These are oil cakes and hulls, whose elimination and/or recovery are essential to avoid the problems associated with the management of such solid waste. It is also a loss of income for all actors in the sector. Finding a long-term, inexpensive and environmentally viable solution to recycle and transform these cakes into valuable products is therefore of crucial importance for the sustainability of the sector (Primandari et al., 2018; Grover et al., 2019). Significant protein (58\%), nitrogen (3.2$4.5 \%$ ), phosphorus (1.4-2.1\%) and potassium (1.2-1.7\%) contents in Jatropha seed cake were reported by Kumar and Sharma (2008). The presences of these elements were recognized as the organic nutrients sources that are even higher than that of chicken or cow manure. Also, scientific results provide evidence for ways to valorise Jatropha pods in compost (Pandey et al., 2012). Investigations must be undertaken to confirm the effect of the use of compost from byproducts of Jatropha on crop production. It is to contribute to this concern that the present study was initiated with the objective of assessing the impact of various compost-based Jatropha curcas by-products on soil properties, growth parameters and production yields of Sorghum bicolor.

\section{MATERIALS ET METHODS}

\subsection{Presentation of the experimental site}

The study was carried out during the crop years 2015, 2016 and 2017 at the experimental site of the agricultural research station of Saria (Figure 1). 


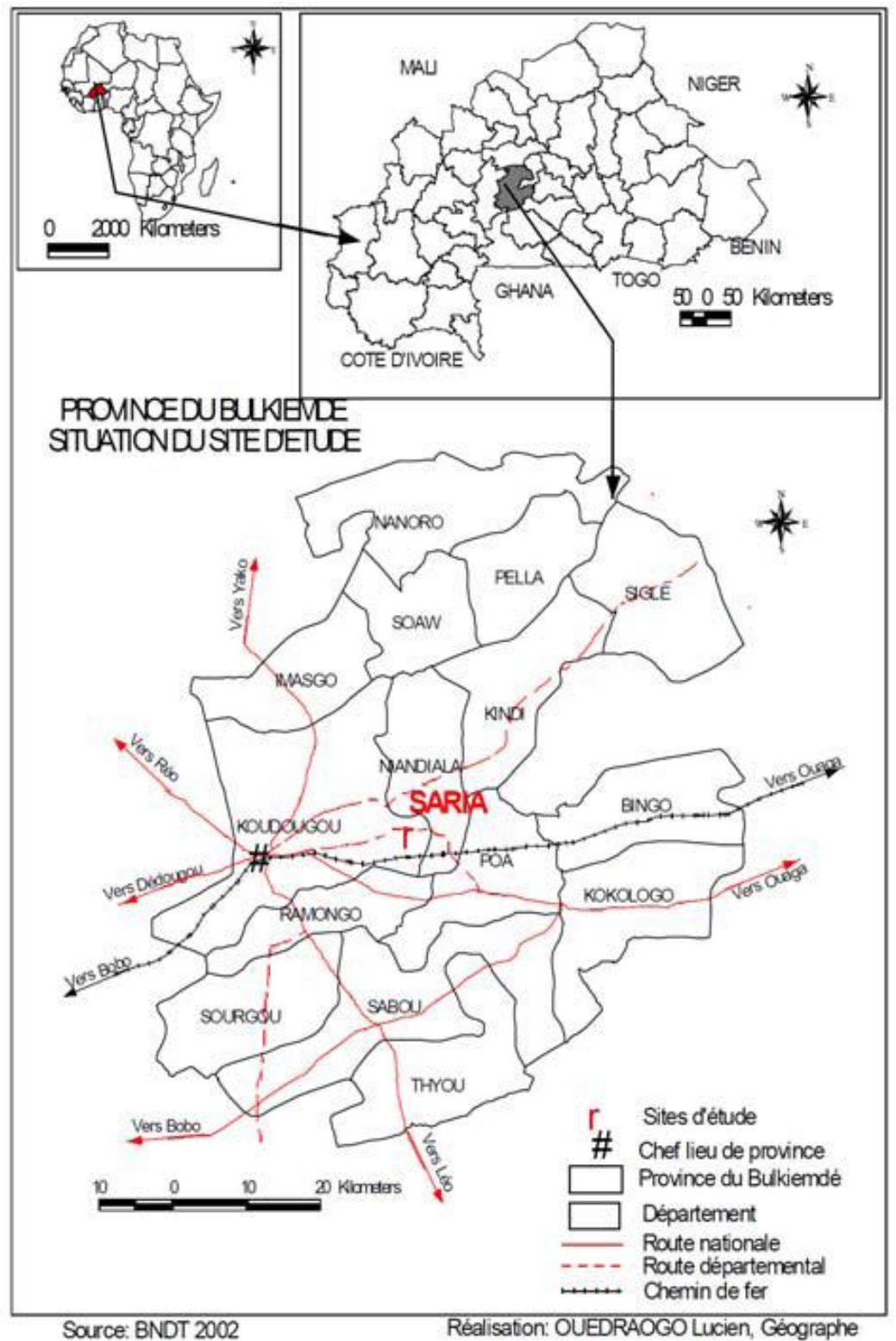

Figure 1: Saria localization map (Yélémou et al., 2013)

\subsection{Pedoclimatic conditions of the experimental site}

The experimental site is located in the Sudano-Sahelian zone with an average annual rainfall of $800 \mathrm{~mm}$ which extends from May to October with large inter and intra annual fluctuations. The average temperature is about $30^{\circ} \mathrm{C}$ per year. Relative humidity is less than $20 \%$ in the dry season and exceeds $60 \%$ in the rainy season (Mando et al., 2005). The Saria agronomy station has a meteorological monitoring station with daily monitoring of rainfall, evapotranspiration and 
atmospheric temperature. Rainfall data for the three campaigns and the mean are presented in figures 2 .

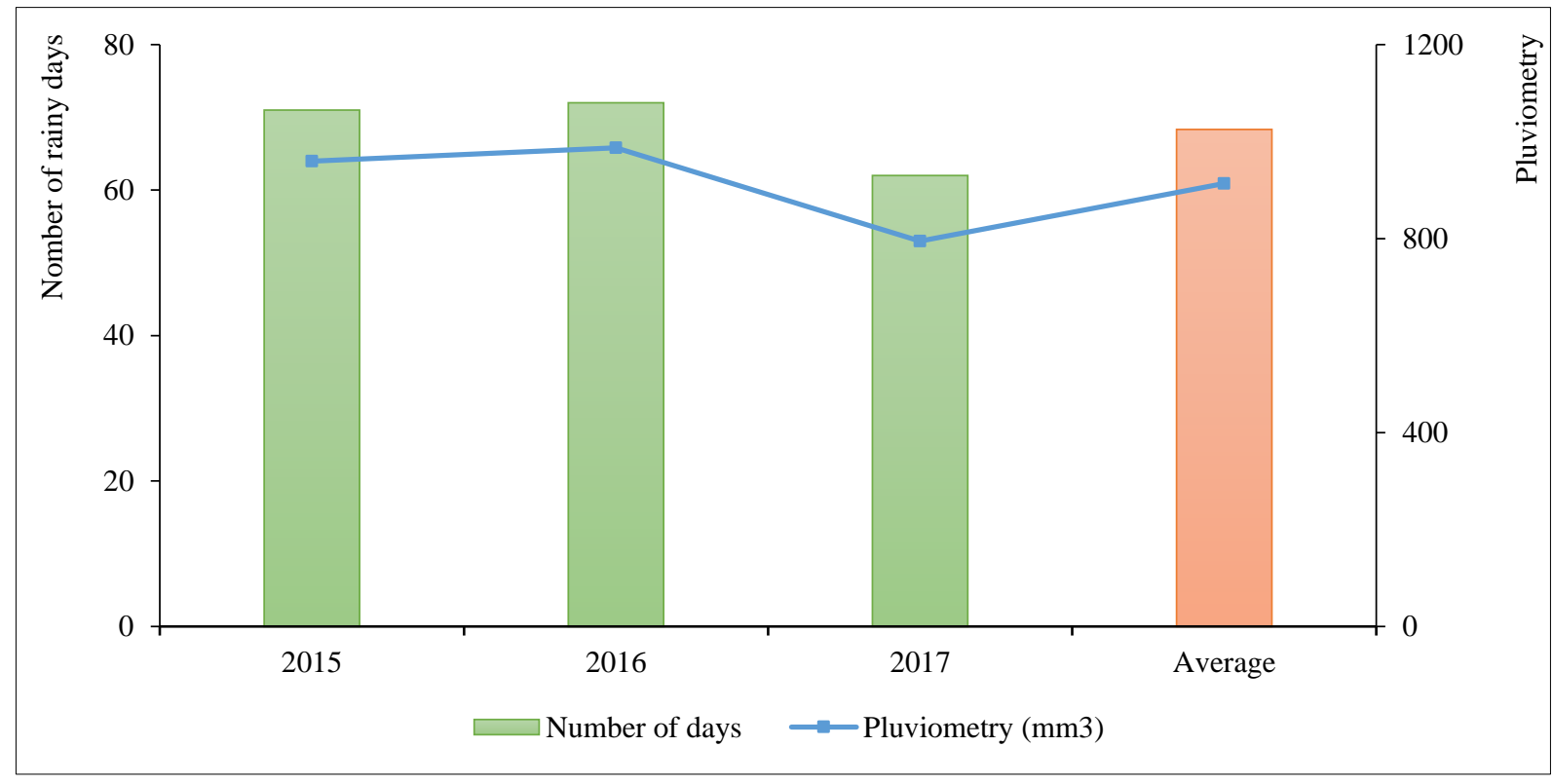

Figure 2: Cumulative rainfall and number of rainy days per season

\subsection{Plant material}

The culture system set up corresponds to a monoculture of Sorghum bicolor, variety ICSV 1049 (Figure 3), which technical data sheet (Agridata, 2013) is given in table 1. 


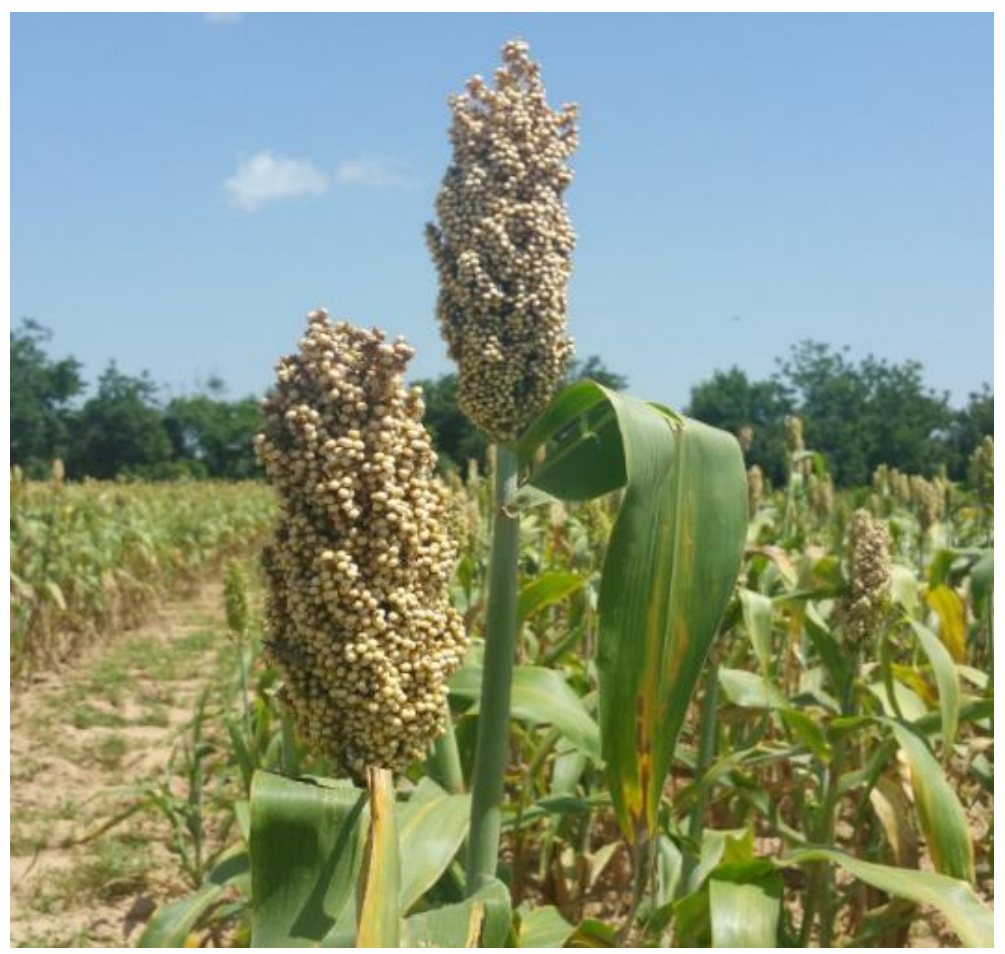

Figure 3: Sorghum bicolor, variety ICSV 1049

Table 1: Technical data sheet of the test plant

\begin{tabular}{|ll|}
\hline Name & ICSV 1049 \\
\hline Cycle & $105-110$ days \\
\hline Station yield & $4 \mathrm{t} / \mathrm{ha}$ \\
\hline Yield in peasant environment & $1-1.5 \mathrm{t} / \mathrm{ha}$ \\
\hline Rainfall of growing areas & $\begin{array}{l}700- \\
\mathrm{mm}\end{array}$ \\
\hline
\end{tabular}

\subsection{Treatments used}

The treatments correspond to 13 composts formulations of Jatropha curcas based composts. The table 2 shows the compositions of the different compost formulations. 
Table 2: List of applicated composts

\begin{tabular}{ll}
\hline Codes & \multicolumn{1}{c}{ Treatments } \\
\hline G_S & Jatropha pod alone \\
G+CP & Jatropha pod + Compost plus \\
G+BV & Jatropha pod + Cow dung \\
T_S & Jatropha cake alone \\
T+CP & Jatropha cake + Compost plus \\
T+BV & Jatropha cake + Crow dung \\
P+CP & Straw of sorghum + Compost plus \\
P_S & Straw of sorghum alone \\
G+DA & Jatropha pod + Slaughterhouse waste \\
T+DA & Jatropha Cake + Slaughterhouse \\
& waste \\
BM_S & Biomass of Jatropha alone \\
BM+CP & Biomass of Jatropha + Compost plus \\
BM+BV & Biomass of Jatropha + Cow dung \\
\hline
\end{tabular}

\subsection{Experimental layout}

The experimental layout is a complete randomised block (Figure 4), with elementary plots of $5.20 \times 4 \mathrm{~m}$ with $1 \mathrm{~m}$ separated and 4 blocks with $2 \mathrm{~m}$ separated. For each treatment, a dose of 5 $\mathrm{t} / \mathrm{ha}$ or $10.4 \mathrm{~kg}$ of compost was applied to each unit plot at the beginning of the campaign, except in the control plot. A control plot was considered in each block. After spreading the various substrates (composts), plowing is done to the cattle at $15-20 \mathrm{~cm}$ deep. An extended dose of NPK is given 15 days after sowing and urea 30 days after weeding. 


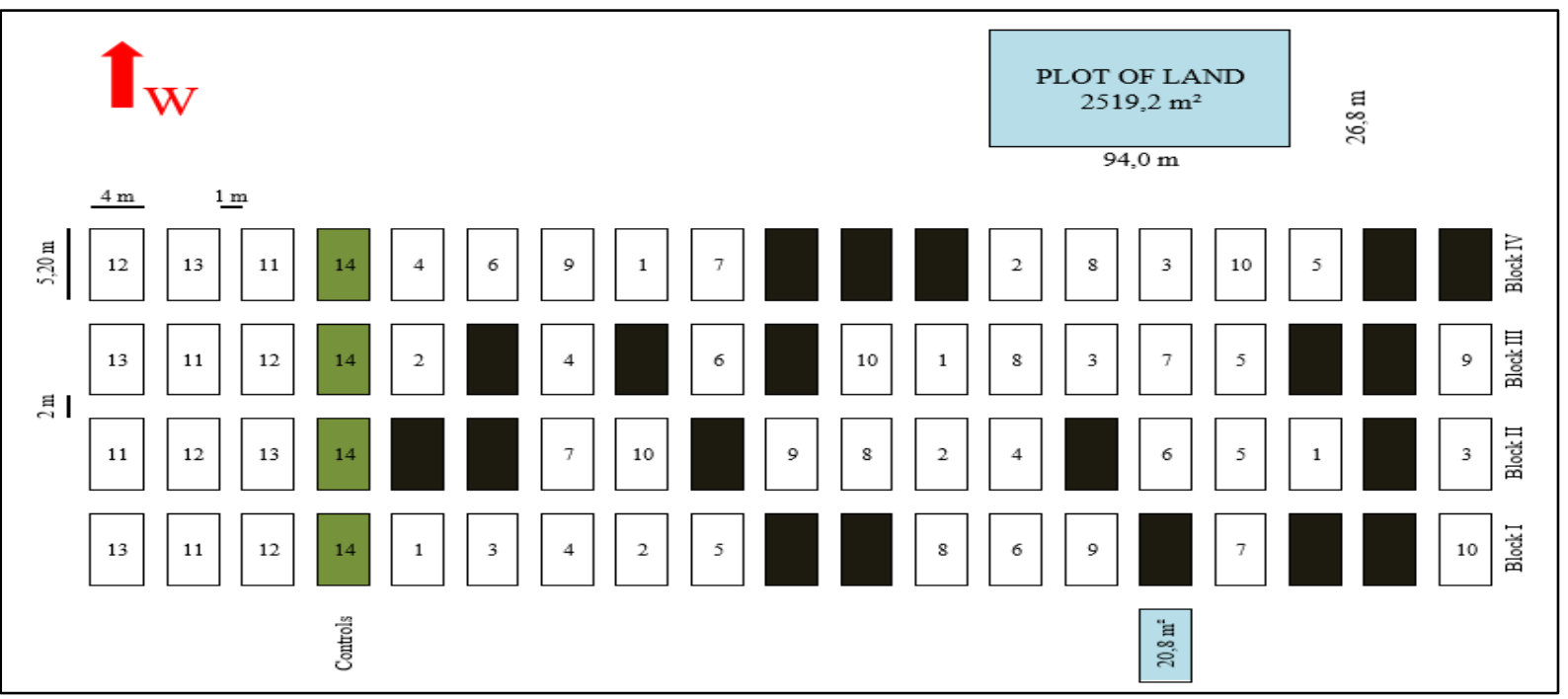

(The plots in black have not been considered in the experiment)

Figure 4: The experimental field

\subsection{Evaluation of soil fertility parameters of the different treatments}

- The $\mathrm{pH}-\mathrm{H}_{2} \mathrm{O}$ and $\mathrm{pH}-\mathrm{KCl}$ were measured by the electrometric glass electrode method using a $\mathrm{pH}$ meter in a mass to volume ratio $(1 \mathrm{~g} / 2.5 \mathrm{~mL}$ ). The soil/water suspension (or $\mathrm{KCl}$ solution) was stirred for one hour before reading.

- Total organic carbon was determined using the method described by Walkley and Black (2003) with modifications. The organic carbon is oxidised in a concentrated sulphuric medium by excess potassium dichromate; as this oxidation is incomplete (on average $75 \%$ ), the results were corrected by multiplying by the ratio 100/75. The rate of organic matter is then obtained by the formula: Rate of Organic Matter = Rate of carbon x 1.724.

- Total nitrogen was determined using the Kjeldahl method based on French standards (Norme NF, 1994). The determination is made by attacking the organic matter with concentrated sulphuric acid in the presence of selenium as a catalyst. The organic nitrogen is mineralised and converted to the ammoniacal state as ammonium sulphate $\left(\mathrm{NH}_{4}\right)_{2} \mathrm{SO}_{4}$. Nitrates and nitrites are not converted. The ammoniacal nitrogen thus obtained is determined by colorimetry.

- Total phosphorus and total potassium were determined by the Bray 1 method cited by (Michaelson et al., 1987). This determination is carried out using a mixed solution of ammonium fluoride and hydrochloric acid. This solution allows the extraction of acidsoluble phosphorus. Ammonium fluoride dissolves iron and aluminium phosphates by 
forming complexes with these metals in an acid medium. Total phosphorus is determined by automatic colorimetry and total potassium is determined by flame photometry.

\subsection{Evaluation of sorghum agronomic parameters}

The agronomic parameters evaluated are plant height, weight of 100 seeds and evaluation of seed, panicles and straws yields. Plant height measurements were made successively at three stages of sorghum development (lifted, flowering and maturation). Yield parameters (panicles, seeds, straw) and weight of 100 seeds were evaluated at harvest.

\subsection{Statistical analyses}

All experiments were repeated three times with four replicates per treatment for sorghum seeds production. Data were treated with MS Excel and then subjected to analysis of variance (ANOVA) using XL-Stat 2016 software. Newman-Keuls multiple rank test at the 5\% threshold was used to separate the means.

\section{RESULTS}

\subsection{Effect of Jatropha composts on soil fertility}

The acidity of the soils after application of the different treatments are presented in the table 3 . The results showed a significant variation between the different treatments for the parameters $\mathrm{pH}-\mathrm{H}_{2} \mathrm{O}$ and $\mathrm{pH}-\mathrm{KCl}$. In general, all treatments significantly improved $\mathrm{pH}-\mathrm{H}_{2} \mathrm{O}$ and $\mathrm{pH}-\mathrm{KCl}$ compared to the control. In addition, treatment $\mathrm{G}+\mathrm{BV}$ gave the best values of $\mathrm{pH}-\mathrm{H}_{2} \mathrm{O}$ and $\mathrm{pH}-$ $\mathrm{KCl}$ respectively 5.7 and 5.3.

Table 3: Acidity of soils

\begin{tabular}{lcc}
\hline Treatments & $\mathbf{p H}-\mathbf{H}_{2} \mathbf{O}$ & $\mathbf{p H}-\mathbf{K C l}$ \\
\hline G_S & $5.4 \pm 0.8^{\mathrm{ab}}$ & $5.0 \pm 0.8^{\mathrm{abc}}$ \\
G+CP & $5.2 \pm 0.1^{\mathrm{abc}}$ & $4.8 \pm 0.2^{\mathrm{abc}}$ \\
G+BV & $5.7 \pm 0.8^{\mathrm{a}}$ & $5.3 \pm 0.9^{\mathrm{a}}$ \\
$\mathrm{T} \_S$ & $5.1 \pm 0.3^{\mathrm{abc}}$ & $4.8 \pm 0.7^{\mathrm{abc}}$ \\
$\mathrm{T}+\mathrm{CP}$ & $5.1 \pm 0.4^{\mathrm{abc}}$ & $4.7 \pm 0.4^{\mathrm{abc}}$ \\
$\mathrm{T}+\mathrm{BV}$ & $5.2 \pm 0.5^{\mathrm{abc}}$ & $4.8 \pm 0.6^{\mathrm{abc}}$ \\
P+CP & $5.1 \pm 0.3^{\mathrm{abc}}$ & $4.8 \pm 0.3^{\mathrm{abc}}$ \\
P_S & $5.2 \pm 0.3^{\mathrm{abc}}$ & $4.8 \pm 0.3^{\mathrm{abc}}$ \\
G+DA & $5.0 \pm 0.3^{\mathrm{bc}}$ & $4.6 \pm 0.3^{\mathrm{abc}}$ \\
T+DA & $5.2 \pm 0.4^{\mathrm{abc}}$ & $4.9 \pm 0.4^{\mathrm{abc}}$ \\
BM_S & $5.0 \pm 0.2^{\mathrm{bc}}$ & $4.6 \pm 0.1^{\mathrm{bc}}$ \\
BM+CP & $5.4 \pm 0.8^{\mathrm{ab}}$ & $5.3 \pm 1.0^{\mathrm{ab}}$
\end{tabular}




\begin{tabular}{lcc} 
BM+BV & $4.9 \pm 0.1^{\mathrm{bc}}$ & $4.5 \pm 0.2^{\mathrm{c}}$ \\
Control & $4.7 \pm 0.3^{\mathrm{c}}$ & $4.4 \pm 0.2^{\mathrm{c}}$ \\
\hline Pr $>\mathrm{F}$ & 0.001 & 0.001 \\
\hline Significant & Yes & Yes
\end{tabular}

For each variable, values that have the same subscript are not significantly different according to Newman-Keuls test at $5 \%$ level.

Legend: G_S (Jatropha pod alone), G+CP (Jatropha pod + Compost+), G+BV (Jatropha pod + Cow dung), T_S (Jatropha cake alone), T+CP (Jatropha cake + Compost+), T+BV (Jatropha cake + Crow dung), P+CP (Straw of sorghum + Compost+), P_S (Straw of sorghum alone), G+DA (Jatropha pod + Slaughterhouse waste), T+DA (Jatropha cake + Slaughterhouse waste), BM_S (Biomass of Jatropha alone), BM+CP (Biomass of Jatropha + Compost+), BM+BV (Biomass of Jatropha + Cow dung)

The table 4 shows the physicochemical properties of the different soils after application of Jatropha curcas composts. Apart from potassium, all other parameters evaluated varied significantly between treatments. Thus, treatment $\mathrm{BM}+\mathrm{CP}$ presented the best values of $\mathrm{OM}(0.61$ $\pm 0.04 \%)$, carbon $(3.54 \pm 0.23 \mathrm{~g} / \mathrm{kg}$ of soil), nitrogen $(0.29 \pm 0.04 \mathrm{~g} / \mathrm{kg}$ of soil $)$ and treatment $\mathrm{T}+\mathrm{CP}$ presented the best value of phosphorus $(0.07 \pm 0.02 \mathrm{~g} / \mathrm{kg}$ of soil $)$.

Table 4: Physicochemical parameters of soil

\begin{tabular}{|c|c|c|c|c|c|c|}
\hline Treatments & OM (\%) & $\begin{array}{c}\text { Carbon } \\
\text { (g/kg soil) }\end{array}$ & $\begin{array}{l}\text { Nitrogen } \\
\text { (g/kg soil) }\end{array}$ & $\begin{array}{c}\text { Phosphorus } \\
\text { (g/kg soil) }\end{array}$ & $\begin{array}{l}\text { Potassium } \\
\text { (g/kg soil) }\end{array}$ & $\mathbf{C} / \mathbf{N}$ \\
\hline G_S & $0.51 \pm 0.04^{\mathrm{bcd}}$ & $2.95 \pm 0.21^{b c d}$ & $0.22 \pm 0.03^{b c}$ & $0.04 \pm 0.00^{b c}$ & $1.05 \pm 0.09^{\mathrm{a}}$ & $14 \pm 2^{a}$ \\
\hline $\mathrm{G}+\mathrm{CP}$ & $0.43 \pm 0.07^{\mathrm{d}}$ & $2.49 \pm 0.41^{\mathrm{d}}$ & $0.25 \pm 0.03^{a b c}$ & $0.05 \pm 0.01^{b c}$ & $1.06 \pm 0.08^{\mathrm{a}}$ & $10 \pm 1^{b}$ \\
\hline $\mathrm{G}+\mathrm{BV}$ & $0.46 \pm 0.07^{\mathrm{cd}}$ & $2.64 \pm 0.39^{\mathrm{cd}}$ & $0.21 \pm 0.03^{c}$ & $0.05 \pm 0.01^{b c}$ & $1.00 \pm 0.04^{\mathrm{a}}$ & $13 \pm 1^{a b}$ \\
\hline T_S & $0.57 \pm 0.07^{\mathrm{ab}}$ & $3.32 \pm 0.38^{a b}$ & $0.26 \pm 0.05^{a b c}$ & $0.05 \pm 0.01^{b c}$ & $1.00 \pm 0.09^{\mathrm{a}}$ & $13 \pm 2^{a b}$ \\
\hline $\mathrm{T}+\mathrm{CP}$ & $0.56 \pm 0.01^{\mathrm{ab}}$ & $3.27 \pm 0.07^{\mathrm{ab}}$ & $0.27 \pm 0.05^{a b c}$ & $0.07 \pm 0.02^{\mathrm{a}}$ & $1.00 \pm 0.09^{\mathrm{a}}$ & $12 \pm 1^{\mathrm{ab}}$ \\
\hline $\mathrm{T}+\mathrm{BV}$ & $0.50 \pm 0.06^{\mathrm{bcd}}$ & $2.88 \pm 0.37^{b c d}$ & $0.26 \pm 0.05^{a b c}$ & $0.06 \pm 0.02^{a b}$ & $0.87 \pm 0.05^{\mathrm{a}}$ & $11 \pm 2^{a b}$ \\
\hline $\mathrm{P}+\mathrm{CP}$ & $0.47 \pm 0.08^{\mathrm{bcd}}$ & $2.71 \pm 0.48^{b c d}$ & $0.23 \pm 0.03^{a b c}$ & $0.06 \pm 0.01 \mathrm{ab}$ & $0.94 \pm 0.12^{\mathrm{a}}$ & $12 \pm 1^{\mathrm{ab}}$ \\
\hline P_S & $0.48 \pm 0.01^{b c d}$ & $2.80 \pm 0.03^{b c d}$ & $0.21 \pm 0.02^{\mathrm{c}}$ & $0.03 \pm 0.01^{\mathrm{c}}$ & $0.96 \pm 0.13^{\mathrm{a}}$ & $14 \pm 1^{\mathrm{a}}$ \\
\hline $\mathrm{G}+\mathrm{DA}$ & $0.53 \pm 0.03^{a b c d}$ & $3.08 \pm 0.20^{\mathrm{abcd}}$ & $0.22 \pm 0.03^{a b c}$ & $0.05 \pm 0.01^{b c}$ & $1.07 \pm 0.09^{\mathrm{a}}$ & $14 \pm 1^{a}$ \\
\hline $\mathrm{T}+\mathrm{DA}$ & $0.53 \pm 0.03^{\mathrm{abcd}}$ & $3.08 \pm 0.16^{\mathrm{abcd}}$ & $0.24 \pm 0.04^{a b c}$ & $0.04 \pm 0.01^{b c}$ & $1.01 \pm 0.12^{\mathrm{a}}$ & $13 \pm 1^{\mathrm{ab}}$ \\
\hline BM_S & $0.51 \pm 0.03^{\mathrm{bcd}}$ & $2.98 \pm 0.20^{\mathrm{bcd}}$ & $0.28 \pm 0.03^{\mathrm{ab}}$ & $0.04 \pm 0.00^{b c}$ & $0.94 \pm 0.12^{\mathrm{a}}$ & $11 \pm 1^{\mathrm{ab}}$ \\
\hline $\mathrm{BM}+\mathrm{CP}$ & $0.61 \pm 0.04^{\mathrm{a}}$ & $3.54 \pm 0.23^{\mathrm{a}}$ & $0.29 \pm 0.04^{\mathrm{a}}$ & $0.06 \pm 0.01^{b c}$ & $1.01 \pm 0.17^{\mathrm{a}}$ & $13 \pm 1^{\mathrm{ab}}$ \\
\hline $\mathrm{BM}+\mathrm{BV}$ & $0.54 \pm 0.04^{a b c}$ & $3.13 \pm 0.25^{a b c}$ & $0.28 \pm 0.02^{a b}$ & $0.05 \pm 0.01^{b c}$ & $0.96 \pm 0.06^{\mathrm{a}}$ & $11 \pm 1^{a b}$ \\
\hline Control & $0.47 \pm 0.05^{b c d}$ & $2.73 \pm 0.31^{\mathrm{bcd}}$ & $0.22 \pm 0.03^{a b c}$ & $0.04 \pm 0.00^{b c}$ & $1.04 \pm 0.07^{\mathrm{a}}$ & $13 \pm 1^{\mathrm{ab}}$ \\
\hline $\operatorname{Pr}>F$ & 0.000 & 0.000 & 0.000 & 0.000 & 0.530 & 0.007 \\
\hline Significant & Yes & Yes & Yes & Yes & No & Yes \\
\hline
\end{tabular}

For each variable, values that have the same subscript are not significantly different according to Newman-Keuls test at $5 \%$ level.

Legend: G_S (Jatropha pod alone), G+CP (Jatropha pod + Compost+), G+BV (Jatropha pod + Cow dung), T_S (Jatropha cake alone), T+CP (Jatropha cake + Compost + ), T+BV (Jatropha cake + Crow dung), P+CP (Straw of sorghum + Compost+), P_S (Straw of sorghum alone), G+DA (Jatropha pod + Slaughterhouse waste), T+DA (Jatropha cake + 
Slaughterhouse waste), BM_S (Biomass of Jatropha alone), BM+CP (Biomass of Jatropha + Compost+), BM+BV (Biomass of Jatropha + Cow dung)

\subsection{Effect of Jatropha composts on the growth of Sorghum bicolor}

The following figures (5, 6 and 7) represent the height growth of Sorghum cobs in the 2015, 2016 and 2017 crop years. The results $(\mathrm{n}=20)$ are expressed in $\mathrm{cm}$ as an average \pm standard deviation. In general, there is a significant statistical difference regardless of the campaign and measurement period.

For the 2015 season (Figure 5), exception of lifted period, all treatments showed a similar growth of Sorghum ears compared to the Control $(70 \mathrm{~cm}-139 \mathrm{~cm})$. Only BM_S $(100 \mathrm{~cm}-169 \mathrm{~cm})$, $\mathrm{BM}+\mathrm{CP}(100 \mathrm{~cm}-175 \mathrm{~cm})$ and $\mathrm{BM}+\mathrm{BV}(92 \mathrm{~cm}-162 \mathrm{~cm})$ treatments showed the best height growth compared to control. In 2016 (Figure 6), all treatments-based Jatropha leaf (BM_S, $\mathrm{BM}+\mathrm{CP}$ and $\mathrm{BM}+\mathrm{BV}$ ) showed statistically the best Sorghum ears height growth regardless of measurement period compared to the control with the lowest height values $(32 \mathrm{~cm}-106 \mathrm{~cm}$ $158 \mathrm{~cm}$ ). For the 2017 season (Figure 7), we have the same observations as in 2016 for the lifted and flowering periods. Treatments BM_S, BM+CP and T+BV gave the best statistical growth in ears height regardless of the measurement period. Control heights recorded were the lowest over the three measurement periods.

Overall, the 2016 season showed the best growth in Sorghum ears height compared to the 2015 and 2017 seasons for all measurement periods.

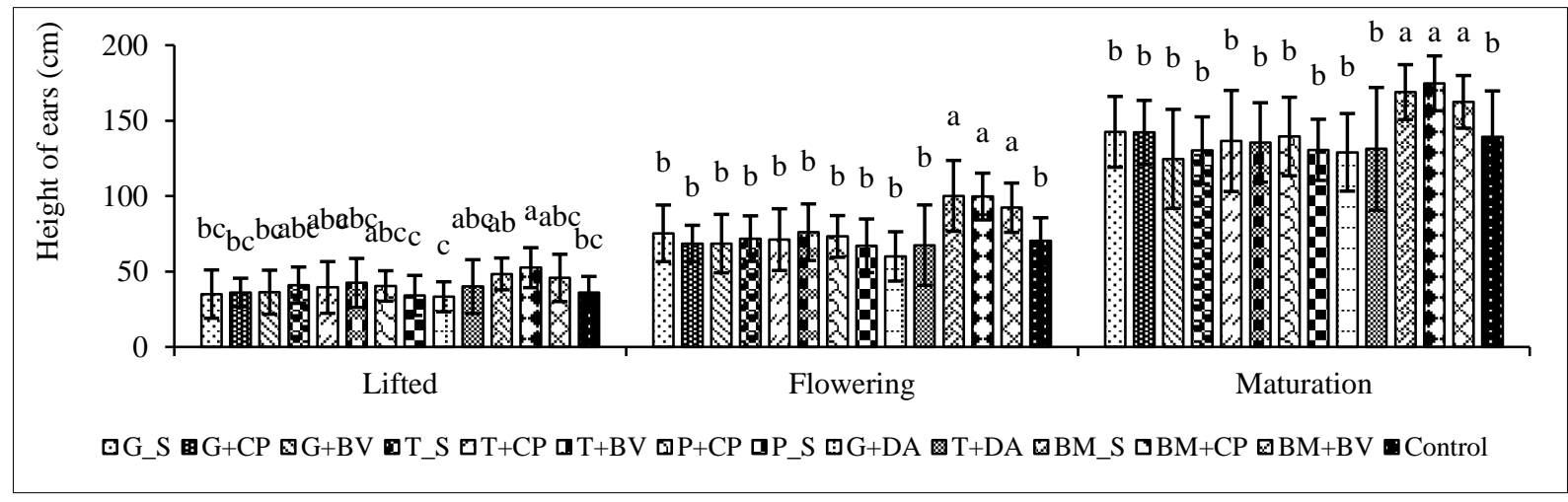

For each measurement period, values that have the same subscript are not significantly different according to Newman-Keuls test at 5\% level.

Legend: G_S (Jatropha pod alone), G+CP (Jatropha pod + Compost+), G+BV (Jatropha pod + Cow dung), T_S (Jatropha cake alone), $\mathrm{T}+\mathrm{CP}($ Jatropha cake + Compost+), T+BV (Jatropha cake + Crow dung), P+CP (Straw of sorghum + Compost+), P_S (Straw of sorghum alone), G+DA (Jatropha pod + Slaughterhouse waste), T+DA (Jatropha cake + Slaughterhouse waste), BM_S (Biomass of Jatropha alone), BM+CP (Biomass of Jatropha + Compost+), BM+BV (Biomass of Jatropha + Cow dung)

Figure 5: Sorghum's plant height growth, Campaign 2015 


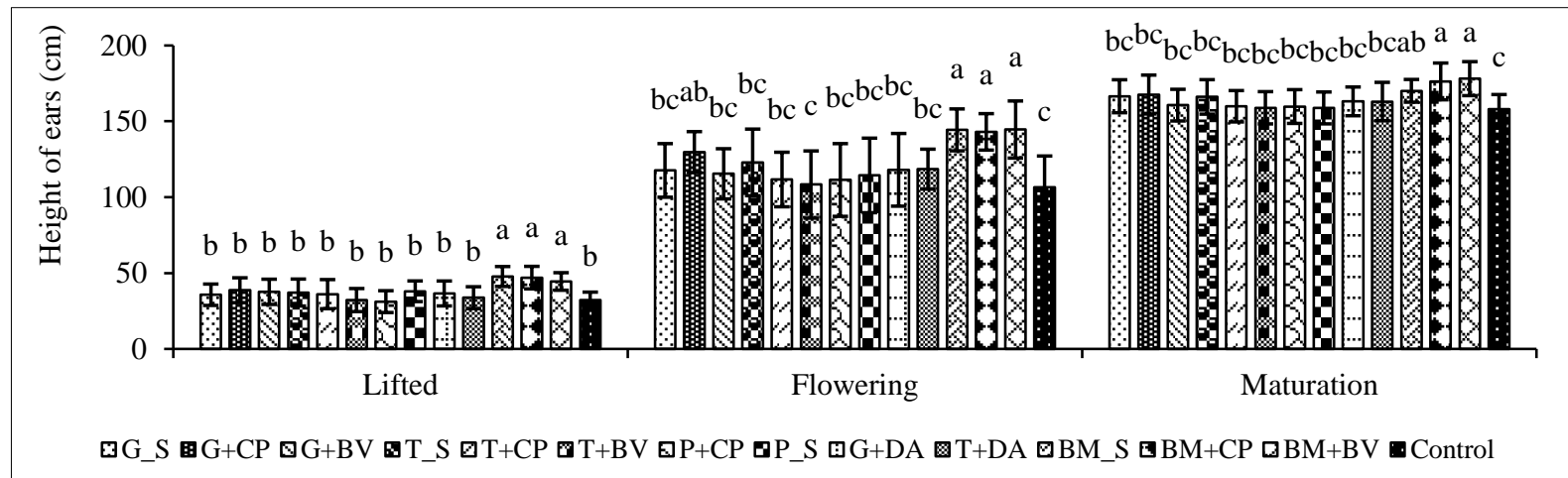

For each measurement period, values that have the same subscript are not significantly different according to Newman-Keuls test at 5\% level.

Legend: G_S (Jatropha pod alone), G+CP (Jatropha pod + Compost+), G+BV (Jatropha pod + Cow dung), T_S (Jatropha cake alone), $\mathrm{T}+\mathrm{CP}($ Jatropha cake + Compost + ), T+BV (Jatropha cake + Crow dung), P+CP (Straw of sorghum + Compost+), P_S (Straw of sorghum alone), G+DA (Jatropha pod + Slaughterhouse waste), T+DA (Jatropha cake + Slaughterhouse waste), BM_S (Biomass of Jatropha alone), BM+CP (Biomass of Jatropha + Compost+), BM+BV (Biomass of Jatropha + Cow dung)

Figure 6: Sorghum's plant height growth, Campaign 2016

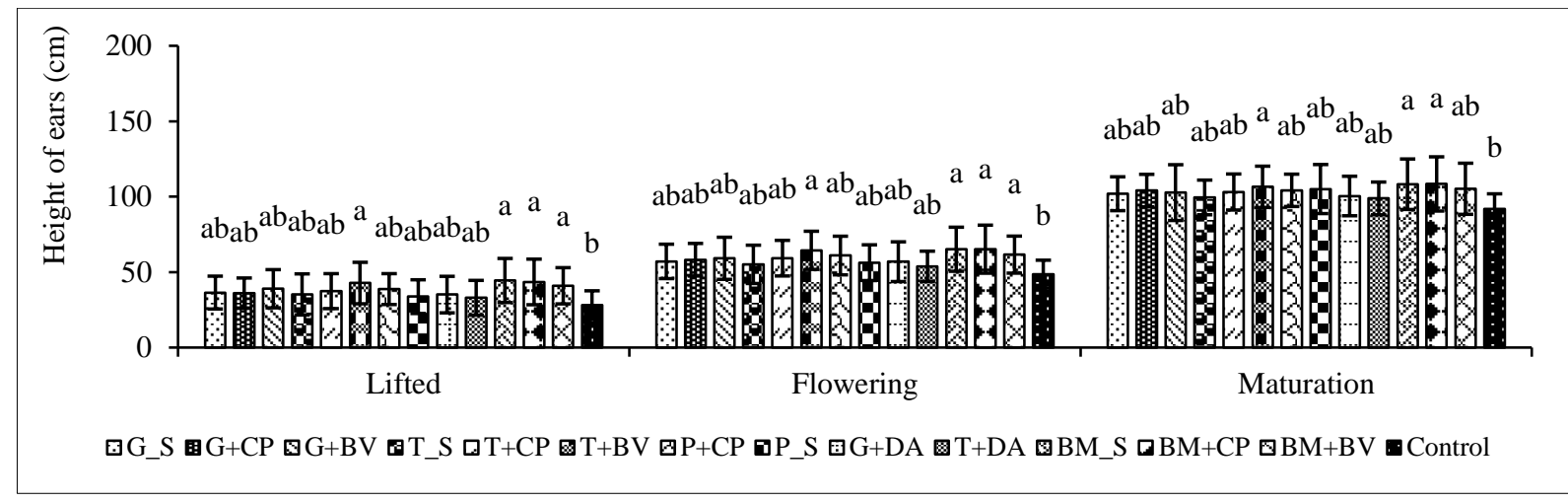

For each measurement period, values that have the same subscript are not significantly different according to Newman-Keuls test at $5 \%$ level.

Legend: G_S (Jatropha pod alone), G+CP (Jatropha pod + Compost+), G+BV (Jatropha pod + Cow dung), T_S (Jatropha cake alone), $\mathrm{T}+\mathrm{CP}$ (Jatropha cake + Compost+), T+BV (Jatropha cake + Crow dung), P+CP (Straw of sorghum + Compost+), P_S (Straw of sorghum alone), G+DA (Jatropha pod + Slaughterhouse waste), T+DA (Jatropha cake + Slaughterhouse waste), BM_S (Biomass of Jatropha alone), $\mathrm{BM}+\mathrm{CP}$ (Biomass of Jatropha + Compost+), BM+BV (Biomass of Jatropha + Cow dung)

Figure 7: Sorghum's plant height growth, Campaign 2017

\subsection{Effect of Jatropha composts on sorghum crop yields}

Sorghum panicle, seed and straw production yields for the 2015, 2016 and 2017 seasons were summarised in table 5. The results are presented as mean \pm standard deviation $(n=4)$ and expressed in t/ha and in grams for the weight of 100 seeds. 
For the 2015 season, there is a statistical difference regardless of the treatment for measured yields. Yield values (in t/ha) range from $1.4 \pm 0.2$ to $2.7 \pm 0.6$ for straw, $0.6 \pm 0.1$ to $1.8 \pm 0.1$ for panicles, $0.4 \pm 0.1$ to $1.3 \pm 0.5$ for seeds. The best straw and seed yields were obtained with the $\mathrm{BM}+\mathrm{CP}$ treatment and for panicles with the 3 Jatropha biomass-based compost treatments (BM_S, BM+CP and BM+BV). The lowest yields were recorded with the control treatment.

All yields in the following two years showed no significant difference regardless of treatment. In 2016, G_S recorded the highest straws yield $(6.4 \pm 0.8 \mathrm{t} / \mathrm{ha})$ and $\mathrm{BM}+\mathrm{BV}$ recorded the highest panicle yield $(2.5 \pm 0.9 \mathrm{t} / \mathrm{ha})$ and seed yield $(1.8 \pm 0.8 \mathrm{t} / \mathrm{ha})$ compared to the control that gave the lowest values. In 2017 , the best straw $(1.6 \pm 0.0 \mathrm{t} / \mathrm{ha})$, panicle $(0.9 \pm 0.0 \mathrm{t} / \mathrm{ha})$ and seeds $(0.6 \pm$ $0.2 \mathrm{t} / \mathrm{ha}$ ) yields were obtained with the T_S and BM+CP treatments compared to the other treatments and the control.

According to the weight of 100 seeds, a statistical difference was only noted for the 2017 season but with more or less the same weight values. Nevertheless, slightly heavier seeds are noted for the 2017 season.

In general, the 2016 season was the most productive with higher yields of sorghum straws, panicles and seeds compared to the 2015 and 2017 seasons. 
Volume: 07, Issue: 04 "July-August 2021"

Table 5: Sorghum crop yields and weight of 100 seeds

\begin{tabular}{|c|c|c|c|c|c|c|c|c|c|c|c|c|}
\hline \multirow[b]{2}{*}{ Treatments } & \multicolumn{4}{|c|}{ Campaign 2015} & \multicolumn{4}{|c|}{ Campaign 2016} & \multicolumn{4}{|c|}{ Campaign 2017} \\
\hline & $\begin{array}{c}\text { Straws } \\
\text { (t/ha) }\end{array}$ & $\begin{array}{c}\text { Panicles } \\
\text { (t/ha) }\end{array}$ & Seeds (t/ha) & $\begin{array}{c}\text { Weight of } \\
100 \text { seeds }(g)\end{array}$ & $\begin{array}{c}\text { Straws } \\
\text { (t/ha) }\end{array}$ & $\begin{array}{c}\text { Panicles } \\
\text { (t/ha) }\end{array}$ & Seeds (t/ha) & $\begin{array}{c}\text { Weight of } \\
100 \text { seeds (g) }\end{array}$ & $\begin{array}{c}\text { Straws } \\
\text { (t/ha) }\end{array}$ & $\begin{array}{c}\text { Panicles } \\
\text { (t/ha) }\end{array}$ & Seeds (t/ha) & $\begin{array}{c}\text { Weight of } \\
100 \text { seeds }(\mathrm{g})\end{array}$ \\
\hline G_S & $2.1 \pm 0.6^{\mathrm{ab}}$ & $1.2 \pm 0,3^{\mathrm{ab}}$ & $0.9 \pm 0.2^{a b c}$ & $2.5 \pm 0.5^{\mathrm{a}}$ & $6.4 \pm 0.8^{a}$ & $2.1 \pm 0.2^{\mathrm{a}}$ & $1.6 \pm 0.2^{\mathrm{a}}$ & $2.2 \pm 0.1^{\mathrm{a}}$ & $0.9 \pm 0.1^{a}$ & $0.6 \pm 0.1^{a}$ & $0.3 \pm 0.2^{\mathrm{a}}$ & $2.4 \pm 0.3^{b}$ \\
\hline $\mathrm{G}+\mathrm{CP}$ & $1.9 \pm 0.2^{a b}$ & $0.9 \pm 0.2^{\mathrm{ab}}$ & $0.6 \pm 0.2^{a b c}$ & $2.0 \pm 0.1^{\mathrm{a}}$ & $5.6 \pm 2.3^{\mathrm{a}}$ & $2.0 \pm 0.3^{\mathrm{a}}$ & $1.5 \pm 0.3^{\mathrm{a}}$ & $2.2 \pm 0.2^{\mathrm{a}}$ & $0.9 \pm 0.1^{\mathrm{a}}$ & $0.6 \pm 0.2^{\mathrm{a}}$ & $0.4 \pm 0.2^{\mathrm{a}}$ & $2.6 \pm 0.1^{a b}$ \\
\hline $\mathrm{G}+\mathrm{BV}$ & $1.4 \pm 0.4^{b}$ & $0.7 \pm 0.2^{b}$ & $0.5 \pm 0.2^{b c}$ & $2.2 \pm 0.3^{\mathrm{a}}$ & $5.4 \pm 0.8^{a}$ & $1.9 \pm 0.3^{\mathrm{a}}$ & $1.4 \pm 0.4^{\mathrm{a}}$ & $2.2 \pm 0.1^{\mathrm{a}}$ & $0.9 \pm 0.2^{\mathrm{a}}$ & $0.6 \pm 0.1^{\mathrm{a}}$ & $0.3 \pm 0.2^{\mathrm{a}}$ & $2.4 \pm 0.3^{b}$ \\
\hline T_S & $1.7 \pm 0.4^{\mathrm{ab}}$ & $1.0 \pm 0.5^{\mathrm{ab}}$ & $0.8 \pm 0.4^{a b c}$ & $2.2 \pm 0.3^{\mathrm{a}}$ & $5.6 \pm 0.8^{a}$ & $2.1 \pm 0.2^{\mathrm{a}}$ & $1.4 \pm 0.2^{\mathrm{a}}$ & $2.4 \pm 0.2^{a}$ & $1.6 \pm 0.0^{\mathrm{a}}$ & $0.9 \pm 0.0^{\mathrm{a}}$ & $0.6 \pm 0.2^{\mathrm{a}}$ & $2.8 \pm 0.1^{\mathrm{ab}}$ \\
\hline $\mathrm{T}+\mathrm{CP}$ & $1.7 \pm 0.6^{\mathrm{ab}}$ & $1.2 \pm 0.5^{\mathrm{ab}}$ & $0.8 \pm 0.4^{a b c}$ & $2.6 \pm 0.4^{\mathrm{a}}$ & $6.1 \pm 2.0^{\mathrm{a}}$ & $1.8 \pm 0.6^{\mathrm{a}}$ & $1.3 \pm 0.5^{\mathrm{a}}$ & $2.3 \pm 0.0^{\mathrm{a}}$ & $1.3 \pm 0.0^{\mathrm{a}}$ & $0.7 \pm 0.3^{\mathrm{a}}$ & $0.4 \pm 0.2^{\mathrm{a}}$ & $3.0 \pm 0.2^{\mathrm{a}}$ \\
\hline $\mathrm{T}+\mathrm{BV}$ & $1.9 \pm 0.3^{\mathrm{ab}}$ & $1.1 \pm 0.1^{\mathrm{ab}}$ & $0.7 \pm 0.1^{\mathrm{abc}}$ & $2.3 \pm 0.1^{\mathrm{a}}$ & $4.4 \pm 0.4^{\mathrm{a}}$ & $1.9 \pm 0.3^{\mathrm{a}}$ & $1.3 \pm 0.4^{\mathrm{a}}$ & $2.3 \pm 0.1^{\mathrm{a}}$ & $0.7 \pm 0.2^{\mathrm{a}}$ & $0.5 \pm 0.0^{\mathrm{a}}$ & $0.3 \pm 0.0^{\mathrm{a}}$ & $2.7 \pm 0.1^{\mathrm{ab}}$ \\
\hline $\mathrm{P}+\mathrm{CP}$ & $1.8 \pm 0.5^{a b}$ & $0.9 \pm 0.2^{a b}$ & $0.6 \pm 0.2^{a b c}$ & $2.3 \pm 0.3^{\mathrm{a}}$ & $5.4 \pm 0.7^{\mathrm{a}}$ & $1.9 \pm 0.4^{\mathrm{a}}$ & $1.3 \pm 0.3^{\mathrm{a}}$ & $2.2 \pm 0.1^{\mathrm{a}}$ & $0.5 \pm 0.2^{\mathrm{a}}$ & $0.4 \pm 0.1^{\mathrm{a}}$ & $0.3 \pm 0.1^{\mathrm{a}}$ & $2.6 \pm 0.3^{a b}$ \\
\hline P_S & $1.6 \pm 0.2^{\mathrm{ab}}$ & $0.7 \pm 0.4^{b}$ & $0.5 \pm 0.3^{b c}$ & $2.1 \pm 0.2^{\mathrm{a}}$ & $4.2 \pm 1.3^{\mathrm{a}}$ & $1.6 \pm 0.4^{\mathrm{a}}$ & $1.1 \pm 0.3^{\mathrm{a}}$ & $2.2 \pm 0.2^{\mathrm{a}}$ & $0.6 \pm 0.1^{a}$ & $0.4 \pm 0.1^{\mathrm{a}}$ & $0.2 \pm 0.0^{\mathrm{a}}$ & $2.4 \pm 0.3^{b}$ \\
\hline $\mathrm{G}+\mathrm{DA}$ & $1.8 \pm 0.5^{\mathrm{ab}}$ & $1.0 \pm 0.2^{\mathrm{ab}}$ & $0.7 \pm 0.2^{\mathrm{abc}}$ & $2.3 \pm 0.1^{\mathrm{a}}$ & $4.4 \pm 2.0^{\mathrm{a}}$ & $2.0 \pm 0.6^{\mathrm{a}}$ & $1.4 \pm 0.5^{\mathrm{a}}$ & $2.3 \pm 0.2^{\mathrm{a}}$ & $1.2 \pm 0.0^{\mathrm{a}}$ & $0.7 \pm 0.4^{\mathrm{a}}$ & $0.5 \pm 0.2^{\mathrm{a}}$ & $2.3 \pm 0.2^{b}$ \\
\hline $\mathrm{T}+\mathrm{DA}$ & $1.5 \pm 0.3^{a b}$ & $0.9 \pm 0.3^{a b}$ & $0.7 \pm 0.3^{a b c}$ & $2.5 \pm 0.4^{\mathrm{a}}$ & $5.5 \pm 1.1^{\mathrm{a}}$ & $2.2 \pm 0.6^{\mathrm{a}}$ & $1.6 \pm 0.7^{\mathrm{a}}$ & $2.3 \pm 0.1^{\mathrm{a}}$ & $0.5 \pm 0.2^{\mathrm{a}}$ & $0.4 \pm 0.1^{\mathrm{a}}$ & $0.2 \pm 0.1^{\mathrm{a}}$ & $2.3 \pm 0.2^{b}$ \\
\hline BM_S & $2.5 \pm 0.8^{a b}$ & $1.7 \pm 0.7^{\mathrm{a}}$ & $1.2 \pm 0.6^{a b}$ & $2.1 \pm 0.1^{\mathrm{a}}$ & $5.7 \pm 1.6^{\mathrm{a}}$ & $2.2 \pm 0.4^{\mathrm{a}}$ & $1.6 \pm 0.3^{\mathrm{a}}$ & $2.4 \pm 0.1^{\mathrm{a}}$ & $1.3 \pm 0.1^{\mathrm{a}}$ & $0.7 \pm 0.3^{\mathrm{a}}$ & $0.5 \pm 0.1^{a}$ & $2.5 \pm 0.1^{a b}$ \\
\hline $\mathrm{BM}+\mathrm{CP}$ & $2.7 \pm 0.6^{\mathrm{a}}$ & $1.8 \pm 0.5^{\mathrm{a}}$ & $1.3 \pm 0.5^{\mathrm{a}}$ & $2.2 \pm 0.3^{\mathrm{a}}$ & $5.0 \pm 1.9^{\mathrm{a}}$ & $2.3 \pm 0.8^{\mathrm{a}}$ & $1.6 \pm 0.6^{\mathrm{a}}$ & $2.3 \pm 0.0^{\mathrm{a}}$ & $1.5 \pm 0.3^{\mathrm{a}}$ & $0.9 \pm 0.2^{\mathrm{a}}$ & $0.6 \pm 0.2^{\mathrm{a}}$ & $2.6 \pm 0.3^{a b}$ \\
\hline $\mathrm{BM}+\mathrm{BV}$ & $2.6 \pm 0.9^{a b}$ & $1.7 \pm 0.6^{\mathrm{a}}$ & $1.2 \pm 0.6^{\mathrm{ab}}$ & $2.3 \pm 0.2^{\mathrm{a}}$ & $5.9 \pm 2.5^{\mathrm{a}}$ & $2.5 \pm 0.9^{\mathrm{a}}$ & $1.8 \pm 0.8^{\mathrm{a}}$ & $2.3 \pm 0.1^{\mathrm{a}}$ & $1.4 \pm 0.3^{\mathrm{a}}$ & $0.8 \pm 0.2^{\mathrm{a}}$ & $0.5 \pm 0.1^{\mathrm{a}}$ & $2.8 \pm 0.2^{\mathrm{ab}}$ \\
\hline Control & $1.4 \pm 0.2^{b}$ & $0.6 \pm 0.1^{b}$ & $0.4 \pm 0.1^{c}$ & $1.9 \pm 0.0^{\mathrm{a}}$ & $3.3 \pm 1.0^{\mathrm{a}}$ & $1.5 \pm 0.2^{\mathrm{a}}$ & $1.1 \pm 0.2^{\mathrm{a}}$ & $2.1 \pm 0.1^{\mathrm{a}}$ & $1.0 \pm 0.2^{\mathrm{a}}$ & $0.6 \pm 0.2^{\mathrm{a}}$ & $0.3 \pm 0.1^{\mathrm{a}}$ & $2.5 \pm 0.4^{\mathrm{ab}}$ \\
\hline $\operatorname{Pr}>\mathrm{F}$ & 0.005 & 0.000 & 0.002 & 0.043 & 0.276 & 0.362 & 0.566 & 0.061 & 0.191 & 0.322 & 0.129 & 0.003 \\
\hline Significant & Yes & Yes & Yes & No & No & No & No & No & No & No & No & Yes \\
\hline
\end{tabular}

For each campaign and variable. values that have the same subscript are not significantly different according to Newman-Keuls test at 5\% level

Legend: G_S (Jatropha pod alone).G+CP (Jatropha pod + Compost+).G+BV (Jatropha pod + Cow dung). T_S (Jatropha cake alone). T+CP (Jatropha cake + Compost+). T+BV (Jatropha cake + Crow dung). P+CP (Straw of sorghum + Compost+).P_S (Straw of sorghum alone).G+DA (Jatropha pod + Slaughterhouse waste). T+DA (Jatropha cake + Slaughterhouse waste). BM_S (Biomass of Jatropha alone). BM+CP (Biomass of Jatropha + Compost+). BM+BV (Biomass of Jatropha + Cow dung) 


\subsection{Effect of treatments on agronomic parameters and comparison between campaigns}

The table 6 shows the effect of the seasons on the parameters studied. It shows that the 2016 season gave the best growth in height of sorghum ears and the best production yields compared to the 2015 and 2017 seasons. However, the 2017 season presented the heaviest seeds.

Table 6: Effect of seasons on studied parameters

\begin{tabular}{lccccc}
\hline Campaigns & Height growth (cm) & Panicles (t/ha) & Seeds (t/ha) & Straws (t/ha) & $\begin{array}{c}\text { Weight of 100 } \\
\text { seeds (g) }\end{array}$ \\
\hline 2016 & $164^{\mathrm{a}}$ & $2.0^{\mathrm{a}}$ & $1.4^{\mathrm{a}}$ & $5.2^{\mathrm{a}}$ & $2.3^{\mathrm{b}}$ \\
2015 & $144^{\mathrm{b}}$ & $1.1^{\mathrm{b}}$ & $0.8^{\mathrm{b}}$ & $1.9^{\mathrm{b}}$ & $2.2^{\mathrm{b}}$ \\
2017 & $101^{\mathrm{c}}$ & $0.6^{\mathrm{c}}$ & $0.4^{\mathrm{c}}$ & $1.0^{\mathrm{c}}$ & $2.6^{\mathrm{a}}$ \\
\hline Pr > F & 0.000 & 0.000 & 0.000 & 0.000 & 0.000 \\
Significant & Yes & Yes & Yes & Yes & Yes \\
\hline
\end{tabular}

For each variable, values that have the same subscript are not significantly different according to Newman-Keuls test at $5 \%$ level

\subsection{Compost properties and correlations between studied parameters}

The figure 8 shows a principal component analysis based on the physicochemical properties of the soil and the agronomic traits of the sorghum of the different composts. The results show a positive correlation between ear height and straw, seed and panicle yields. Ear height was negatively correlated with seed weight. In addition, ear height, straw, seed and panicle yields were strongly associated with BM_S, BM+CP and BM+BV treatments. Seed weight was associated with the G_S, T_S and T+CP treatments.

Regarding the chemical composition of the soil, treatments BM_S, BM+CP, BM+BV, T_S, $\mathrm{T}+\mathrm{CP}$ and $\mathrm{T}+\mathrm{BV}$ were strongly associated with nitrogen, carbon and phosphorus content while treatments $\mathrm{G}_{-} \mathrm{S}$ and $\mathrm{G}+\mathrm{BV}$ were associated with $\mathrm{C} / \mathrm{N}$ ratio, $\mathrm{pH}-\mathrm{H}_{2} \mathrm{O}$ and $\mathrm{pH}-\mathrm{KCl}$. 
International Journal of Agriculture and Environmental Research

ISSN: 2455-6939

Volume: 07, Issue: 04 "July-August 2021"

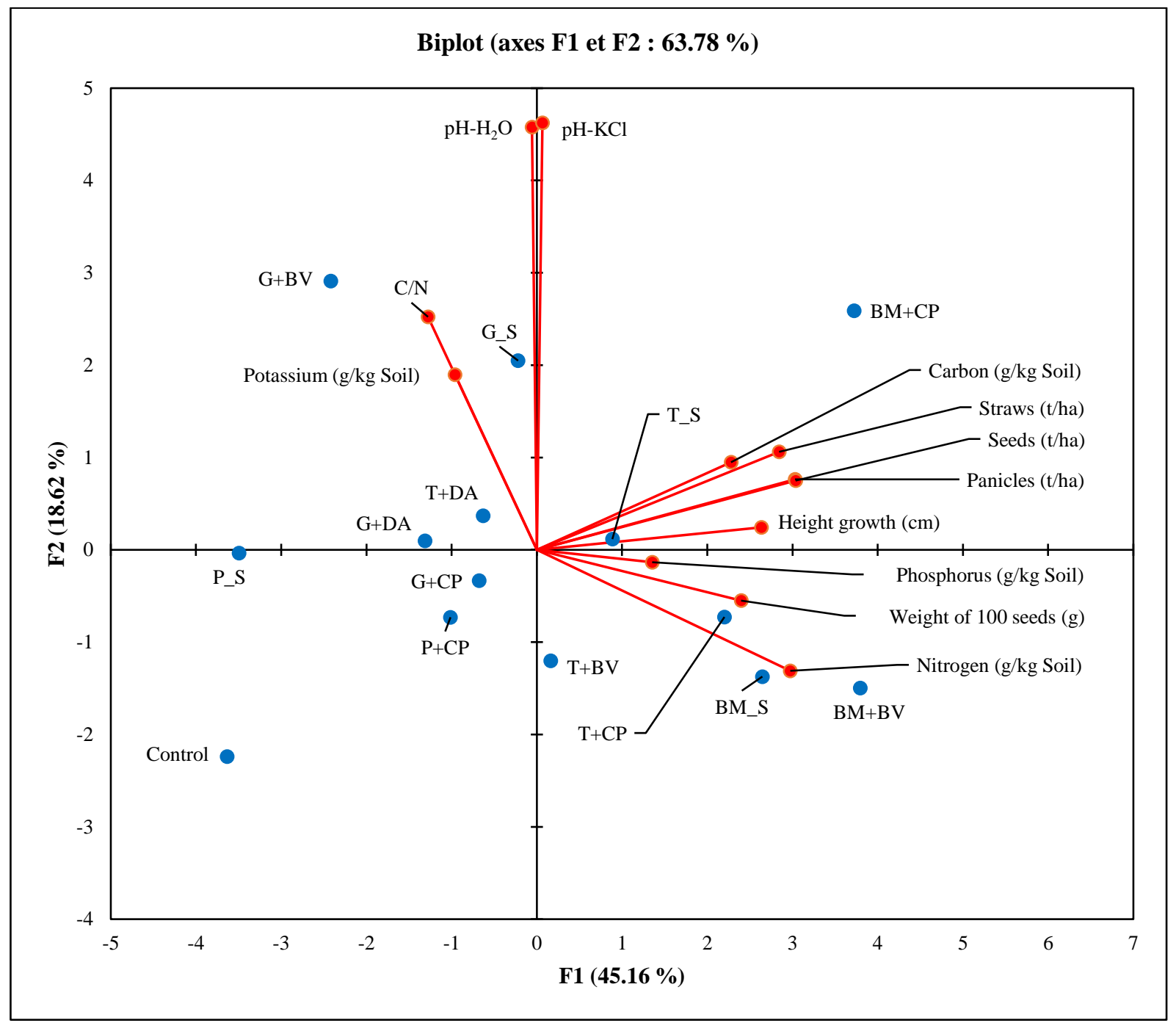

Legend: G_S (Jatropha pod alone), G+CP (Jatropha pod + Compost+), G+BV (Jatropha pod + Cow dung), T_S (Jatropha cake alone), $\mathrm{T}+\mathrm{CP}($ Jatropha cake + Compost+), T+BV (Jatropha cake + Crow dung), P+CP (Straw of sorghum + Compost+), P_S (Straw of sorghum alone), G+DA (Jatropha pod + Slaughterhouse waste), T+DA (Jatropha cake + Slaughterhouse waste), BM_S (Biomass of Jatropha alone), BM+CP (Biomass of Jatropha + Compost+), BM+BV (Biomass of Jatropha + Cow dung)

\section{Figure 8: Principal Components Analysis}

The hierarchical ascending classification (Figure 9) allowed the composts to be divided into four classes. Class 1 consists of the composts $G \_S, G+C P, T+C P, T+B V$ and P+CP. Class 2 consists of the control treatment and the treatments P_S, T_S, T+DA, G+BV and G+DA. Class 3 consists of the BM_S and BM+BV treatment. Class 4 consists of the composts BM+CP. In this classification, class 3 and class 4 composts are of particular interest as they are strongly associated with seed, straw and panicle yields, ear height and improving soil fertility. 


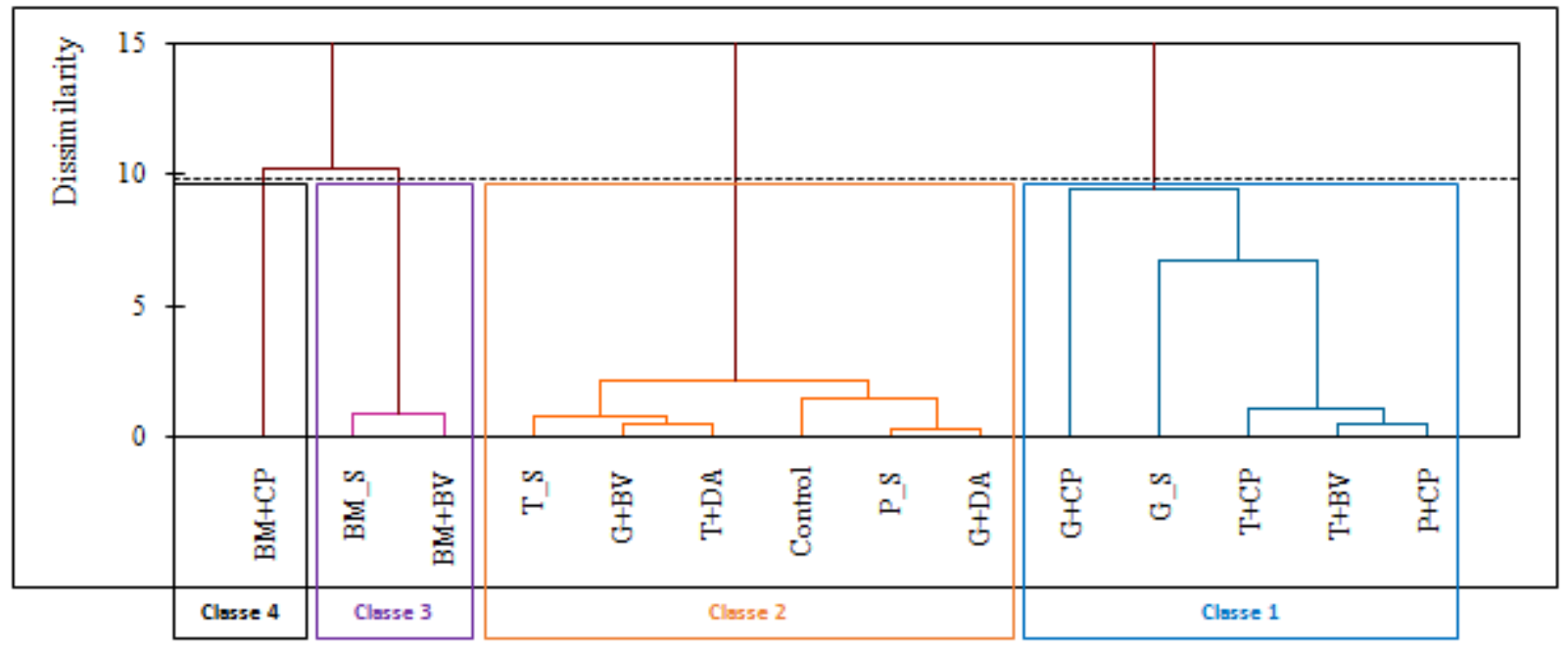

Legend: G_S (Jatropha pod alone), G+CP (Jatropha pod + Compost+), G+BV (Jatropha pod + Cow dung), T_S (Jatropha cake alone), $\mathrm{T}+\mathrm{CP}$ (Jatropha cake + Compost+), T+BV (Jatropha cake + Crow dung), P+CP (Straw of sorghum + Compost+), P_S (Straw of sorghum alone), G+DA (Jatropha pod + Slaughterhouse waste), T+DA (Jatropha cake + Slaughterhouse waste), BM_S (Biomass of Jatropha alone), BM+CP (Biomass of Jatropha + Compost+), BM+BV (Biomass of Jatropha + Cow dung)

Figure 9: Dendrogram of dissimilarity

\section{DISCUSSION}

Nutrient and organic matter deficiency is one of the major factors limiting crops production (Venkateswarlu et al., 2016). Jatropha by-products can act as an excellent organic fertilizer and soil amendment due to its richness in organic matter and nutrients (Liu et al., 2016; Bai et al., 2017). The present study demonstrated that jatropha by-products amendment could effectively raise soil fertility by increasing $\mathrm{pH}$ and nutrient contents. Indeed, the results revealed that the application of some composts based on the by-products of Jatropha was of great interest, especially in improving soil fertilization and sorghum growth and production parameters. The application of composts-based Jatropha by-products have improved soil $\mathrm{pH}$, nitrogen, carbon and potassium contents compared to the control treatment. In addition, they also have the best $\mathrm{C} / \mathrm{N}$ ratios. The direction of the change in soil $\mathrm{pH}$ as a result of treatments application reflected the initial $\mathrm{pH}$ of the amendment material. The rise in the soil $\mathrm{pH}$ level of the experimental soil after harvesting is an indication of the buffering capacity of compost with Jatropha by-product applied. This enhanced the availability of the soil nutrients resulting in increased crop growth and yield. The increase in $\mathrm{C}, \mathrm{N}, \mathrm{K}$ content and $\mathrm{C} / \mathrm{N}$ ratio of the different treatments compared to the control treatment could be explained by the application of composts into soil, because of the high salinity of composts, increases the salt content as well as soil electrical conductivity (Angelova et al., 2013). The soil carbon increased with the compost application was reported by 
Belal-Hossen and Akther-Hossain (2015) who explain it by the nature of the raw materials used for composting (Atiyeh et al., 2001).

In accordance with the observed improvement of soil fertility parameters, the growth of sorghum was stimulated by compost-based Jatropha by-products. The best results for the growth parameters were obtained with the $\mathrm{BM}+\mathrm{CP}, \mathrm{BM}+\mathrm{BV}$ and BM_S treatments made respectively from Jatropha cake + Slaughterhouse waste, Biomass of Jatropha alone and Biomass of Jatropha + Compost + . These same treatments presented the best panicles yield while BM+CP treatment presented the best straw and seed yields. The T+CP (Jatropha cake + Compost + ) treatment also resulted in the best weights of 100 seeds. The promotion effect was much more significant with BM_S, BM+CP and BM+BV based Jatropha and Slaughterhouse or cow dawn. The positive effects of Jatropha composts on plant growth were also observed by other authors (Van Groenigen et al., 2014; Bityutskii et al., 2016; Ros et al., 2017; Agapit et al., 2018), who found that organic compost impact nutrient availability and thereby increase plant growth and nutrient uptake. The ability of these composts to improve growth and production parameters is therefore linked to their ability to improve soil fertility. These composts probably provided the supply of macronutrients $(\mathrm{N}, \mathrm{P}, \mathrm{K})$ to the plants as compared to control from by contributing in releasing of nutrients. Indeed, according to Ndoutoumou et al. (2019), the mineral element contents of Jatrophacurcas cake (3.8 to $6.4 \%$ nitrogen, 0.9 to $2.8 \%$ phosphorus, 1 to $1.8 \%$ potassium) reveal Jatrophacurcas potential for improvement in agronomy in the context of fertilization. The presence of mineral elements and their content in the substrates plays a major role in plant growth. The plant's vegetative development is closely linked to the presence of nitrogen (Ndoum, 2010). Similar results were reported by Elnasikh et al. (2016) who reported that Jatropha seed cake with its rich nitrogen content can be used to improve nitrogen content of cellulosic wastes with high $\mathrm{C} / \mathrm{N}$ ratio for producing valuable composts.

The comparison of the production parameters between the 3 years of the study shows that the 2016 season was the most productive. The 2016 season had the highest panicle, straw and seed yields. This better productivity of the 2016 season could be explained by the rainfall. Indeed, rainfall records from the Saria station showed that the agricultural season recorded the best rainfall compared to the others. Similar results were reported by Laporte et al. (2002). Their works predict that increases in temperature, precipitation and longer growing seasons associated with climate change should lead to increased net productivity of agricultural crops where soils permit. According to (Huang and Zhang, 2016), water is the key limiting factor to plant growth and productivity in arid and semiarid areas. And precipitation, as the sole source of water replenishment, plays an important role in sustaining particularly in the desert ecosystem and determines the mass transfer process in the soil and vegetation system. 


\section{CONCLUSION}

Modern agriculture faces to new challenges and problems. One of the greatest threats is depletion in soil fertility. Therefore, we must search for news biotechnology to maintain soil fertility and renewal of its natural properties. In this order, the effect of various composts-based Jatropha by products was evaluated. The study showed that Jatropha by-products amendment could effectively raise soil fertility by increasing $\mathrm{pH}$ and nutrient contents and improved Sorghum growth and production parameters. The results also showed positive and significant correlations between panicles yield and seeds yield as well as straws yield. Positive and significant correlations were recorded between seeds yield and straws yield and weight of 100 seeds. These correlations between the different parameters are important of simultaneous improving of growth and crops yield of sorghum. The ACP performed based on measurement parameters permitted to identify the appropriate formulation for any interest parameter. These results supported the best effects of the application of various compost-based by-products of Jatropha curcas in Sorghumbicolor production. Based on these results, we conclude that the application of composts-based Jatropha by-products has positive effect on soil fertility and Sorghum growth and production parameters. The use of these composts constitutes practical benefits of employing organic manure and a good solution for a sustainable farming system.

\section{ACKNOWLEDGEMENTS}

The authors are grateful to the African Union for financial support through the AU-Jatropha Project and to INERA/Saria for technical support.

\section{REFERENCES}

Agapit C., Gigon A., Puga-Freitas R., Zeller B. and Blouin M. 2018. Plant-earthworm interactions: influence of age and proportion of casts in soil on plant growth, morphology and nitrogen uptake, Plant Soil, 424, pp. 49-61.

Agridata. 2013. Fiches techniques sur la culture fourragere du maïs, sorgho, siratro, dolique, niebe et soja, a l'intention des paysans promoteurs d'embouche bovine et ovine.

Angelova V.R., Akova V.I., Artinova N.S. and Ivanov K.I. 2013.The effect of organic amendments on soil chemical characteristics, Bulgarian Journal of Agricultural Science, 19(5), pp. 958-971.

Atiyeh R.M., Edwards C.A., Subler S. and MetzgerJ.D. 2001. Pig manure vermicompost as a component of a horticultural bedding plant medium: Effects on physicochemical 
International Journal of Agriculture and Environmental Research

ISSN: 2455-6939

Volume: 07, Issue: 04 "July-August 2021"

properties and plant growth, Bioresource Technology, 78(1), pp. 11-20. doi: 10.1016/S0960-8524(00)00172-3.

Bai Y., Zang C.,Gu M., Gu C., Shao H., Guan Y., Wang X.,Zhou X., Shana Y., FengK.2017. Sewage sludge as an initial fertility driver for rapid improvement of mudflat salt-soils, Science of the Total Environment, 578, pp. 47-55. doi: 10.1016/j.scitotenv.2016.06.083.

Belal-Hossen M. and Akther-Hossain A.K.M. 2015. Complex impedance and electric modulus studies of magnetic ceramic Ni0.27Cu0.10Zn0.63Fe2O4, Journal of Advanced Ceramics, 4(3), pp. 217-225. doi: 10.1007/s40145-015-0152-2.

Bityutskii N., Kaidun P. and Yakkonen K. 2016. Earthworms can increase mobility and bioavailability of silicon in soil, Soil Biology and Biochemistry, 99, pp. 47-53. doi: 10.1016/j.soilbio.2016.04.022.

Calderón R., Navas-Cortés J.A., Lucena C. and Zarco-Tejada P.J. 2013. 'High-resolution airborne hyperspectral and thermal imagery for early detection of Verticillium wilt of olive using fluorescence, temperature and narrow-band spectral indices, Remote Sensing of Environment. Elsevier Inc., 139, pp. 231-245. doi: 10.1016/j.rse.2013.07.031.

Cano-Asseleih L.M., Plumbley R.A. and Hylands P.J. 1989. Purification and partial characterization of a hemagglutinin from seeds of Jatropha curcas, Journal of Food Biochemistry, 13(1), pp. 1-20. doi: 10.1111/j.1745-4514.1989.tb00381.x.

Derra A.-N., Yélémou B., Sanon K.B., Hilou A., Millogo-Rasolodimby J. and Hien V. 2013. Management patterns of Jatropha curcas: impact on the microbial and the mycorrhizial biomasses in different phyto-geographic zones of Burkina Faso., Advances in Applied Science Research, pp. 256-267. Available at: http://www.pelagiaresearchlibrary.com/ advances-in-applied-science/vol4-iss6/AASR-20130-4-6-256-267.

Diallo H. N. 2011. Sols cultivés et fonctions microbiennes: la gestion des résidus organiques permet-elle de manipuler ces fonctions? Cas de l'Afrique de l'ouest. Université Cheickh Anta Diop, Dakar, Département Santé, Vie et Environnement. 166p.

Elnasikh M.H.,Abuali A.I., Fadlalla H.A., Ali H.A., Babiker A.E. and Mohamed E.A. 2016. Use of Physic Nut (Jatropha curcas L .) Seed Cake in Three Mixtures of Raw Materials for Compost Production, Environment and Natural Resources International Journal (ENRIJ), 1(1), pp. 13-21. 
International Journal of Agriculture and Environmental Research

ISSN: 2455-6939

Volume: 07, Issue: 04 "July-August 2021"

Ganry F., Feller C., Harmand J-M. and Guiber H. 2001. Management of soil organic matter in semiarid Africa for annual cropping systems, Nutrient Cycling in Agroecosystems, 61, pp. $105-118$.

Van Groenigen J.W., Lubbers I.M., Vos H.M.J., Brown G.G., De Deyn G.B. and Van Groenigen K.J. 2014. Earthworms increase plant production: a meta-analysis, Scientific Reports, 4(2), pp. 1-7. doi: 10.1038/srep06365.

Huang L. and Zhang Z. 2016. Effect of rainfall pulses on plant growth and transpiration of two xerophytic shrubs in a revegetated desert area: Tengger Desert, China, Catena, 137, pp. 269-276. doi: 10.1016/j.catena.2015.09.020.

Ishola T.M. and Ishola E.T. 2019. Composting and Sustainable Development, Encyclopedia of Sustainability in Higher Education, pp. 1-8. doi: https://doi.org/10.1007/978-3-31963951-2_122-1.

Jayasingh M. 2003. The use of Bio-diesel by the Indian Railways, In: Proceedings of the National Workshop 5-8 August, Pune, India.

Khan M.A., Khan S., Ankita, Ahmed I. and Masood N. 2019. Comparison of age estimates from Sagittae, Lapilli and Sterisci in Spotted snakehead, Channa puncta (Bloch, 1793) collected from the River Ganga', Xenobiotics, Environnement and Functional Biology, pp. 141-149. Available at: https://www.researchgate.net/publication/331859527.

Kumar A. and Sharma S. 2008. An evaluation of multipurpose oil seed crop for industrial uses (Jatropha curcas L.): A review, Industrial Crops and Products, 28(1), pp. 1-10. doi: 10.1016/j.indcrop.2008.01.001.

Laporte M.F., Duchesne L.C. and Wetzel S. 2002. Effect of rainfall patterns on soil surface $\mathrm{CO}_{2}$ efflux, soil moisture, soil temperature and plant growth in a grassland ecosystem of northern Ontario, Canada: Implications for climate change, BMC Ecology, 2(10), pp. 1-6. doi: 10.1186/1472-6785-2-10.

Liu T., Chen X., Hu F., Ran W., Shen Q., Li H., Whalen J.K. 2016. arbon-rich organic fertilizers to increase soil biodiversity: Evidence from a meta-analysis of nematode communities, Agriculture, Ecosystems and Environment, 232, pp. 199-207. doi: 10.1016/j.agee.2016.07.015.

Mando A., Ouattara B., Sédogo M., Stroosnijder L., Ouattara K., Brussaard L.and Vanlauwe B. 2005. Long-term effect of tillage and manure application on soil organic fractions and 
International Journal of Agriculture and Environmental Research

ISSN: 2455-6939

Volume: 07, Issue: 04 "July-August 2021"

crop performance under Sudano-Sahelian conditions, Soil and Tillage Research, 80, pp. 95-101. doi: 10.1016/j.still.2004.03.002.

Michaelson G.J., Ping C.L. and Mitchell G.A. 1987. Correlation of Mehlich 3, Bray 1, and ammonium acetate extractable $\mathrm{P}, \mathrm{K}, \mathrm{Ca}$, and $\mathrm{Mg}$ for alaska agricultural soils, Communications in Soil Science and Plant Analysis, 18(9), pp. 1003-1015. doi: 10.1080/00103628709367877.

Ndoum N.M.F. 2010. Etude des facteurs du sol favorables à la croissance de Pericopsis elata (Harms) Var. Meeuwen (Assamela) dans trois unités forestières d'aménagement à l'Est Cameroun. Université de Dschang, Département de foresterie. Mémoire présenté en vue de l'obtention du Diplôme d'Ingénieur des Eaux, Forêts et Chasses, 90p.

Ndoutoumou P.N., Ndong A.N., Anda O.C.C., Midoumbou F.P.N., Ognalaga M. and Missang C.E. 2019. Régénération du cacaoyer (Theobroma cacao L .) sur un substrat à base de compost de Jatropha curcas L., International Journal of Biological and Chemical Sciences, 13(2), pp. 1043-1053.

Norme N.F. 1994. EN 25663, ISO 5663. Mode opératoire pour le dosage de l'azote Kjeldahl. Europe-France. Indice de classement - T 90-110.

Olowoake A.A. 2019. Influence of compost supplemented with Jatropha cake on growth and nutrient uptake of maize (Zea mays L.), African Journal of Organic Agriculture and Ecology, 1, pp. 17-22.

Olowoake A.A., Osunlola O.S. and Ojo J.A. 2018. Influence of compost supplemented with jatropha cake on soil fertility, growth, and yield of maize (zea mays L.) in a degraded soil of Ilorin, Nigeria', International Journal of Recycling of Organic Waste in Agriculture, 7(1), pp. 67-73. doi: 10.1007/s40093-017-0192-4.

Pandey V.C., Singh K., Singh J.S., Kumar A., Singh B. and Singh R.P. 2012. Jatropha curcas: A potential biofuel plant for sustainable environmental development, Renewable and Sustainable Energy Reviews. Elsevier Ltd, 16(5), pp. 2870-2883. doi: 10.1016/j.rser. 2012.02.004.

Powlson D.S., Whitmore A.P. and Goulding K.W.T. 2011. Soil carbon sequestration to mitigate climate change: a critical re-examination to identify the true and the false', European Journal of Soil Science, 62(1), pp. 42-55. doi: 10.1111/j.1365-2389.2010.01342.x. 
International Journal of Agriculture and Environmental Research

ISSN: 2455-6939

Volume: 07, Issue: 04 "July-August 2021"

Primandari S.R.P., Islam A.K.M.A., Yaakob Z. and Chakrabarty S. 2018. Jatropha Curcas L. Biomass Waste and Its Utilization, Advances in Biofuels and Bioenergy, pp. 273-282. doi: 10.5772/intechopen.72803.

Ros M., Raut I., Santisima-Trinidad A.B. and Pascual J.A. 2017. Relationship of microbial communities and suppressiveness of Trichoderma fortified composts for pepper seedlings infected by Phytophthora nicotianae, PLOS ONE, 12(3), pp. 1-16. doi: 10.1371/journal. pone.0174069.

Sama H., Ouattara B., Hilou A., Derra A-N. and Hien V. 2018. Variability of morpho-metric traits and oleaginous biofuel potential of Jatropha curcas L . (Euphorbiaceae) seeds in Burkina Faso, African Journal of Agricultural Research, 13(52), pp. 2911-2918. doi: 10.5897/AJAR2018.13196.

Singh S., Kundu S.S., Negi A.S. and Singh P.N. 2006. Cowpea ( Vigna unguiculata ) legume grains as protein source in the ration of growing sheep, Small Ruminant Research, 64, pp. 247-254. doi: 10.1016/j.smallrumres.2005.04.022.

Tiwari K.N. 2002. Nutrient management for sustainable agriculture, Journal of the Indian Society of Soil Science, 50, pp. 374-377.

Venkateswarlu K., Nirola R., Kuppusamy S., Thavamani P., Naidu R. and Megharaj M. 2016. Abandoned metalliferous mines: ecological impacts and potential approaches for reclamation, Reviews in Environmental Science and Biotechnology, 15(2), pp. 327-354. doi: 10.1007/s11157-016-9398-6.

Walkley A. and Black I.A. 2003. Détermination de la matière organique par dosage du carbone organique dans les sols agricoles: méthode Walkley-Black modifiée, in Méthode d'analyse. Centre d'expertise en analyse environnementale du Québec et Ministère de l'Agriculture, des Pêcheries et de l'Alimentation du Québec. MA. 1010 - WB 1.0 Édition : 2003-03-27, pp. 1-10.

Yélémou B., Yaméogo G., Barro A., Taonda S.J. and Hien V. 2013. La production de sorgho dans un parc à Piliostigma reticulatum en zone nord-soudanienne du Burkina Faso, Tropicultura, 31(3), pp. 154-162. 